\title{
Prospective Zinc Solubilising Bacteria for Enhanced Nutrient Uptake and Growth Promotion in Maize (Zea mays L.)
}

\author{
Praveen Kumar Goteti, Leo Daniel Amalraj Emmanuel, \\ Suseelendra Desai, and Mir Hassan Ahmed Shaik \\ Central Research Institute for Dryland Agriculture, Santoshnagar, Saidabad Post, Hyderabad, Andhra Pradesh 500 059, India \\ Correspondence should be addressed to Praveen Kumar Goteti; writetopraveenkumar@yahoo.com
}

Received 25 June 2013; Accepted 15 October 2013

Academic Editor: David C. Straus

Copyright (C) 2013 Praveen Kumar Goteti et al. This is an open access article distributed under the Creative Commons Attribution License, which permits unrestricted use, distribution, and reproduction in any medium, provided the original work is properly cited.

\begin{abstract}
Zinc $(\mathrm{Zn})$ is one of the essential micronutrients required for optimum plant growth. Substantial quantity of applied inorganic zinc in soil is converted into unavailable form. Zinc solubilising bacteria are potential alternates for zinc supplement. Among 10 strains screened for Zn solubilisation, P29, P33, and B40 produced $22.0 \mathrm{~mm}$ clear haloes on solid medium amended with $\mathrm{ZnCO}_{3}$. Similarly, $\mathrm{P} 17$ and B40 showed $31.0 \mathrm{~mm}$ zone in $\mathrm{ZnO}$ incorporated medium. P29 and B40 showed significant release of $\mathrm{Zn}$ in broth amended with $\mathrm{ZnCO}_{3}(17$ and $16.8 \mathrm{ppm})$ and $\mathrm{ZnO}(18$ and $17 \mathrm{ppm})$, respectively. The $\mathrm{pH}$ of the broth was almost acidic in all the cases ranging from 3.9 to 6.1 in $\mathrm{ZnCO}_{3}$ and from 4.1 to $6.4 \mathrm{in} \mathrm{ZnO}$ added medium. Short term pot culture experiment with maize revealed that seed bacterization with P29 @ $10 \mathrm{~g} \cdot \mathrm{kg}^{-1}$ significantly enhanced total dry mass (12.96 g) and uptake of N (2.268\%), K (2.0\%), Mn (60 ppm), and Zn (278.8 ppm).
\end{abstract}

\section{Introduction}

Zinc is one of the imperative micronutrients required relatively in small concentrations $\left(5-100 \mathrm{mg} \mathrm{kg}^{-1}\right)$ in tissues for healthy growth and reproduction of plants. Zinc deficiency in plants leads to reduced membrane integrity and synthesis of carbohydrates, auxins, nucleotides, cytochromes, and chlorophyll and develops susceptibility to heat stress [1]. Excessive use of zinc fertilizers also poses problems to humans causing the impaired absorption of iron and copper. It is also known to repress male sexuality [2]. The solubility of $\mathrm{Zn}$ is highly dependent upon soil $\mathrm{pH}$ and moisture and hence arid and semiarid areas of Indian agroecosystems are often zinc-deficient.

In India, maize is grown in a wide range of environments, extending from extreme semiarid to subhumid and humid regions. It is grown in about $8.26 \mathrm{Mha}$ with yield being $19.3 \mathrm{Mt}$ (Ministry of Agriculture, Government of India). Voluminous literature indicates that $\mathrm{Zn}$ concentration in the grain is inherently very low, particularly when grown on $\mathrm{Zn}$-deficient soils. The major reason for the widespread occurrence of $\mathrm{Zn}$ deficiency problems in crop plants is attributed to low solubility of $\mathrm{Zn}$ in soils rather than a low total amount of
Zn [3]. Customary application of inorganic zinc partially caters the plant need as $96-99 \%$ of applied $\mathrm{Zn}$ is converted into different insoluble forms depending upon the soil types and physicochemical reactions within 7 days of application [4]. Microbes are potential alternate that could cater plant zinc requirement by solubilising the complex zinc in soil. Several genera of rhizobacteria belonging to Pseudomonas spp. and Bacillus spp. are reported to solubilise zinc. Microbes solubilise the metal forms by protons, chelated ligands, and oxidoreductive systems present on the cell surface and membranes [5-7]. These bacteria also exhibit other traits beneficial to plants, such as production of phytohormones, antibiotics, siderophores, vitamins, antifungal substances, and hydrogen cyanide [8]. In this study we reported the in vitro zinc solubilisation ability of selected strains and their ability to enhance the growth of Zea mays $\mathrm{L}$.

\section{Materials and Methods}

2.1. Bacterial Strains and Culture Conditions. Bacterial strains used in this study were obtained from the culture bank of Central Research Institute for Dryland Agriculture, 
Hyderabad, India. Five each of Pseudomonas spp. were designated as P17, P21, P29, P33, and P74 and Bacillus spp. as B40, B61, B114, B116, and B118. The cultures were originated from composite and rhizospheric soils of diverse rainfed agroecosystems of India. Pseudomonas and Bacillus spp. were maintained on King's B and nutrient agar medium at $4^{\circ} \mathrm{C}$.

2.2. In Vitro Zinc Solubilization Assay. All the isolates were inoculated into liquid mineral salts medium $\left(\mathrm{g} \cdot \mathrm{lit}^{-1}\right)$ specified by Saravanan et al. [9] containing dextrose: 10.0; $\left(\mathrm{NH}_{4}\right)_{2} \mathrm{SO}_{4}$ : 1.0; KCl: $0.2 ; \mathrm{K}_{2} \mathrm{HPO}_{4}$ : 0.1; $\mathrm{MgSO}_{4}: 0.2 ; \mathrm{pH}: 7.0$ and insoluble $\mathrm{Zn}$ compound $\left(\mathrm{ZnO}\right.$ and $\mathrm{ZnCO}_{3}: 0.1 \%$; Agar: $15.0 \mathrm{~g}$ ) and autoclaved at $121^{\circ} \mathrm{C}$ for $20 \mathrm{~min}$. Actively growing cultures of each strain were spot-inoculated $(3 \mu \mathrm{L})$ onto the agar and plates were incubated at $28^{\circ} \mathrm{C}$ for $48 \mathrm{~h}$. The clearing zone around colony was recorded. Quantitative study of zinc solubilization was studied in $150 \mathrm{~mL}$ conical flasks containing $50 \mathrm{~mL}$ of liquid mineral salt medium. The broth was inoculated with $10 \mu \mathrm{L}$ of overnight grown bacterial inoculum and incubated for $72 \mathrm{~h}$ at $160 \mathrm{rpm}$ in an incubator shaker at $28 \pm 2^{\circ} \mathrm{C}$. After incubation, the culture broth was centrifuged and the concentration of $\mathrm{Zn}$ in the supernatant was estimated in atomic absorption spectrophotometer (GBC, Australia).

2.3. Seed Bacterization. Maize seeds of cultivable variety were surface sterilized with $1 \%$ sodium hypochlorite for $5 \mathrm{~min}$ and washed five times with sterile distilled water. Seeds were treated with talc-based inoculum containing $10^{8} \mathrm{cfu} \cdot \mathrm{g}^{-1}$ of each strain with $0.5 \%$ carboxymethylcellulose (CMC) as adhesive.

2.4. Pot Trial. The pot culture experiment was conducted in $10 \mathrm{~kg}$ plastic pots $(20 \mathrm{~cm}$ dia) filled with $9 \mathrm{~kg}$ sterile red soil (presterilized for three consecutive days) with six replications for each treatment. Maize cultivable variety seeds treated with bacterial inoculant were sown and the glasshouse condition was set at $28 \pm 2^{\circ} \mathrm{C}$ and $70 \%$ humidity. Pots were watered once in two days with sterile distilled water until 60 days. The experimental setup consisted of 15 treatments namely, five treatments each of Bacillus and Pseudomonas strains as seed dresser @ $10 \mathrm{mg} \mathrm{kg}^{-1}$ seed (T1 to 10 ), commercially available zinc solubilizing bacteria (T11), farm yard manure (FYM) @ $10 \mathrm{~kg} \cdot$ acre $^{-1}$ (T12), seeds primed by soaking overnight in $1.0 \%$ $\mathrm{ZnSO}_{4}$ (T13), positive control @ $\mathrm{ZnSO}_{4} @ 10 \mathrm{~kg} \cdot \mathrm{acre}^{-1}$ (T14), and uninoculated control (T15).

2.5. Plant Growth Measurement. After 60 days of sowing (DAS), plants were uprooted from the pots carefully and biometric parameters like root volume, shoot length, leaf area (measured by LI 3100, Lincoln, Nebraska, USA leaf area meter), and dry mass of plants were recorded as the indicative of plant growth.

2.6. Nutrient Analyses. Dried plants were finely ground in a mortar and pestle to amorphous powder and $100 \mathrm{mg}$ was taken in $150 \mathrm{~mL}$ conical flask containing $10 \mathrm{~mL}$ nitric acid $\left(\mathrm{HNO}_{3}\right)$ and perchloric acid $\left(\mathrm{HClO}_{4}\right)$ in $9: 4$ ratio. The flasks
TABLE 1: Zinc solubilizing ability of Pseudomonas and Bacillus isolates with insoluble zinc substrates on solid medium.

\begin{tabular}{lcc}
\hline Bacterial isolates & $\begin{array}{c}\text { Solubilization zone diameter (in mm) } \\
\text { ZnCO }_{3}\end{array}$ & ZnO \\
\hline P17 & 20 & 31 \\
P21 & 21 & 24 \\
P29 & 22 & 27 \\
P33 & 22 & 27 \\
P74 & 21 & 23 \\
B40 & 22 & 31 \\
B61 & 18 & 19 \\
B114 & 14 & 17 \\
B116 & 20 & 24 \\
B118 & 20 & 26 \\
\hline
\end{tabular}

were placed on a hot plate and digested at $300^{\circ} \mathrm{C}$ until the entire plant material turned colourless. The extract was taken in $100 \mathrm{~mL}$ volumetric flask and the volume was made to $100 \mathrm{~mL}$ with distilled water. These samples were used for estimation of sodium, potassium, and calcium by flame photometer. Phosphorus was quantified by sulphomolybdic acid method [10]. Total nitrogen content of the plants was estimated by micro-Kjeldahl method [11]. Similarly, micronutrients such as iron, copper, manganese, zinc, and magnesium were estimated by atomic absorption spectrophotometer.

2.7. Statistical Analysis. The values presented are the means of two independent experiments each with six replicates performed at different occasions. Data obtained from all the experiments were subjected to two-way analysis of variance (ANOVA). Mean values between treatments were compared with Fisher's least significant difference (LSD) test $(P<0.05)$.

\section{Results}

3.1. Zinc Solubilization Activity. All the selected strains of Pseudomonas and Bacillus used could effectively solubilize the insoluble $\mathrm{Zn}$ compounds used, namely, $\mathrm{ZnCO}_{3}$ and $\mathrm{ZnO}$, under the assay conditions. The zone of solubilisation was comparatively high in $\mathrm{ZnO}$ amended medium as compared to $\mathrm{ZnCO}_{3}$. Size of the solubilisation zone ranged from 14 to $22 \mathrm{~mm}$ in $\mathrm{ZnCO}_{3}$ and from 17 to $33 \mathrm{~mm}$ in $\mathrm{ZnO}$ incorporated medium. Among the cultures, P29, P33, and B40 showed the highest solubilisation zone in $\mathrm{ZnCO}_{3}(22 \mathrm{~mm})$, whereas $\mathrm{P} 17$ and $\mathrm{B} 40$ showed $31 \mathrm{~mm}$ zone in $\mathrm{ZnO}$ amended medium (Table 1). Quantitative assay for zinc solubilisation revealed that $\mathrm{P} 29, \mathrm{P} 33$, and $\mathrm{B} 40$ were able to dissolve 17,16 , and $16.8 \mathrm{ppm}$ from $\mathrm{ZnCO}_{3}$, respectively, in liquid medium (Figure 1) and they were consistent with the observations on solid medium. However, P17 which was found to be the leading solubilizer on plate agar did not imitate the result in broth amended with $\mathrm{ZnO}$ though significant fall in $\mathrm{pH}$ (4.1) was noted. Instead, P29 showed the highest Zn solubilisation of 18 ppm available $\mathrm{Zn}$, followed by B40 (17 ppm) (Figure 2). Across the treatments, significant reduction of $\mathrm{pH}$ was observed in the broth cultures amended with $\mathrm{ZnCO}_{3}$ 


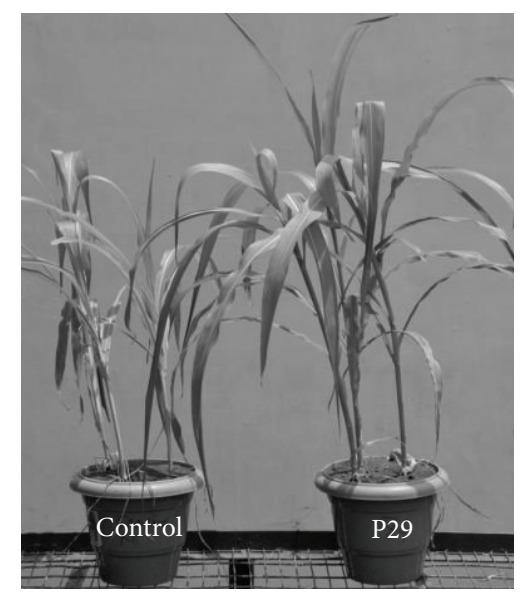

FIGURE 1: Plant growth promotion of maize with zinc solubilizing Pseudomonas sp. strain-P29 (60 DAS).

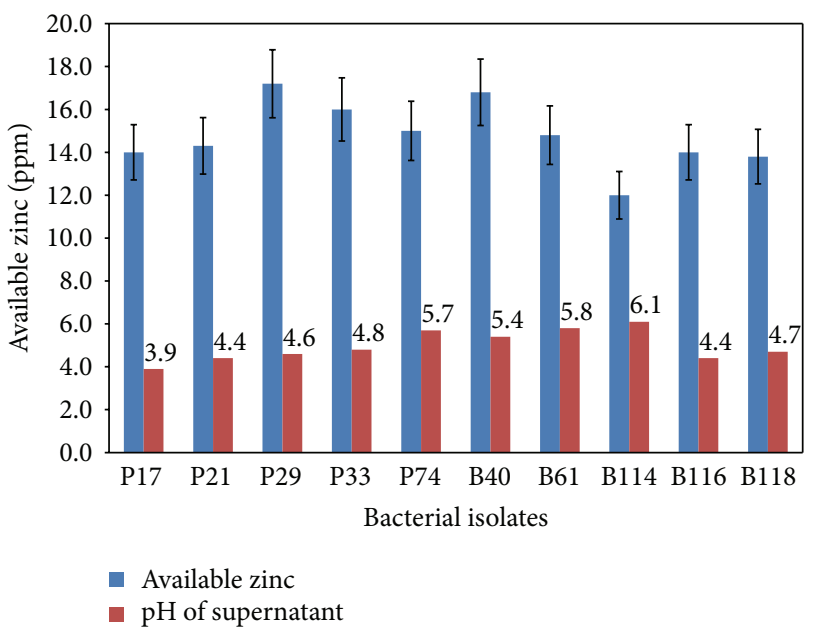

FIgURE 2: Available zinc $\left(\mathrm{mg} \cdot \mathrm{kg}^{-1}\right.$ ) released by bacteria in broth medium containing zinc carbonate.

( $\mathrm{pH}$ 3.9-6.1) and $\mathrm{ZnO}(\mathrm{pH} 4.1-6.4)$. However there was no significant correlation between the $\mathrm{pH}$ and solubilisation of nutrients.

\subsection{Plant Growth Promoting Activity of Bacterial Strains.} Seed bacterization of maize with zinc solubilising Pseudomonas spp. and Bacillus spp. enhanced the plant growth significantly after 60 DAS (Table 2). Among all the treatments, inoculation of maize with talc-based P29 strain showed increased root volume $\left(18.3 \mathrm{~cm}^{3}\right)$. Other growth indicating parameters like total dry mass (TDM) and leaf area (LA) were recorded to be the highest in $\mathrm{ZnSO}_{4}$ treatment with $15.25 \mathrm{~g}$ and $1161.3 \mathrm{~cm}^{2}$, respectively. However, they are statistically on par with P29 treatment where $12.96 \mathrm{~g}$ and $1147.5 \mathrm{~cm}^{2}$ of TDM and LA were recorded, respectively (Figure 1 and Table 2).

3.3. Nutrient Concentrations in Plants. Significant concentration of $\mathrm{N}(2.268 \%)$ and $\mathrm{K}(2.0 \%)$ was observed in P29 treatment. The highest $\mathrm{P}(0.28 \%)$ concentration was noted in B40 treated plants as compared to other treatments (Table 3$)$. The highest sodium $\left(\mathrm{Na}^{+}\right)$concentration in plants was recorded in $\mathrm{Zn}$ primed, $\mathrm{P} 29, \mathrm{P} 33$, and $\mathrm{ZnSO}_{4}$ treatments which were not significantly different. Significant $\mathrm{Ca}$ $(0.434 \%)$ concentration in plant tissues was found in $\mathrm{ZnSO}_{4}$ treatment followed by P74 (0.354\%) and P29 (0.341\%). Na$\mathrm{K}$ ratio was higher with ZSB (0.0047) and priming (0.004) treatment; P29 (0.0033) and B118 (0.0029) also recorded the highest ratio of $\mathrm{Na}-\mathrm{K}$ ions.

P29 significantly enhanced the concentration of $\mathrm{Zn}$ content (278.8 ppm) in plant tissue as high as 36, 32.35, and $43.11 \%$ compared to $\mathrm{Zn}$ priming, $\mathrm{ZnSO}_{4}$, and control treatment, respectively (Table 4$)$. The highest $\mathrm{Mn}(60 \mathrm{ppm})$ concentration was also noted in P29 treatment which is on par with $\mathrm{ZnSO}_{4}$ treatments. Interestingly, P21 treated plants showed the highest quantity of $\mathrm{Fe}(707 \mathrm{ppm})$ which is statistically on par with $\mathrm{B} 40$ treatment (672.8 ppm). $\mathrm{Mg}(0.23 \mathrm{ppm})$ and $\mathrm{Cu}$ (4.8 ppm) were significantly found higher in inorganic $\mathrm{ZnSO}_{4}$ plants.

\section{Discussion}

Solubilisation of zinc can be accomplished by a range of mechanisms, which include excretion of metabolites such as organic acids, proton extrusion, or production of chelating agents $[12,13]$. In addition, production of inorganic acids such as sulphuric acid, nitric acid, and carbonic acid could also facilitate the solubilisation $[8,14]$.

It is apparent from the zinc solubilization data that the solubilization potential varied with each isolate. Organic acid production by microbial isolates has been reported to be a major mechanism of solubilization $[15,16]$. This solubilization property is important in nutrient cycling. Fall in $\mathrm{pH}$ and acidification of medium was noted in all cases. Higher solubilization of the insoluble zinc sources was achieved in $72 \mathrm{~h}$. The zinc solubilizing potential also correlated with the zinc levels that are accumulated by plant leaves. The zinc solubilization in our studies could be due to production of organic acids, like gluconic acids (especially 2-keto-gluconic acids). Zinc phosphate solubilization by a strain of Pseudomonas fluorescens was investigated by Di Simine et al. [17]. They identified that gluconic acids produced in culture medium helped in solubilization of zinc salts. In our present study also, the acidic $\mathrm{pH}$ shown by all the bacterial isolates gives a clue that the solubilization could be due to production of organic acids and higher the production of the same higher is the available zinc in the culture broth (Figure 3). Desai et al. [18] reported that higher availability of $\mathrm{Zn}$ is directly proportional to acidic $\mathrm{pH}$ of the culture broth. However, in some potent strains, $\mathrm{pH}$ did not fall drastically suggesting that in those strains other mechanisms may be active and this aspect is being accentuated.

The present study clearly demonstrated that inoculation with plant growth promoting rhizobacteria significantly enhanced the growth of maize in all dimensions. In this study application of $\mathrm{ZnSO}_{4}$ alone has increased the total dry mass of plants and leaf area. Increased leaf area with 
TABLE 2: Biometric growth parameters of maize seeds treated with ZSBs and inorganic source of zinc.

\begin{tabular}{|c|c|c|c|c|}
\hline Treatment & $\mathrm{RV}(\mathrm{cc})$ & $\mathrm{SL}(\mathrm{cm})$ & TDM (gm) & LA $\left(\mathrm{cm}^{2}\right)$ \\
\hline Control & $9.8^{j}( \pm 0.45)$ & $78.8^{\mathrm{h}}( \pm 3.63)$ & $9.16^{\mathrm{h}}( \pm 0.422)$ & $627.7^{\mathrm{i}}( \pm 28.93)$ \\
\hline $\mathrm{ZnSO}_{4}$ & $13.8^{\mathrm{h}}( \pm 0.64)$ & $85.1^{\mathrm{fg}}( \pm 3.92)$ & $15.25^{\mathrm{a}}( \pm 0.703)$ & $1161.3^{\mathrm{a}}( \pm 53.52)$ \\
\hline Priming & $15.0^{\mathrm{fg}}( \pm 0.69)$ & $96.0^{c}( \pm 4.42)$ & $12.87^{\mathrm{b}}( \pm 0.593)$ & $861.0^{\mathrm{f}}( \pm 39.68)$ \\
\hline B61 & $15.0^{\mathrm{fg}}( \pm 0.69)$ & $97.8^{\mathrm{b}}( \pm 4.51)$ & $11.36^{\mathrm{d}}( \pm 0.523)$ & $908.3^{\mathrm{e}}( \pm 41.86)$ \\
\hline B40 & $15.7^{\mathrm{de}}( \pm 0.72)$ & $92.1^{\mathrm{d}}( \pm 4.24)$ & $11.98^{\mathrm{c}}( \pm 0.552)$ & $955.5^{\mathrm{d}}( \pm 44.04)$ \\
\hline B116 & $16.7^{\mathcal{C}}( \pm 0.77)$ & $110.1^{\mathrm{a}}( \pm 5.07)$ & $12.78^{\mathrm{b}}( \pm 0.589)$ & $1113.8^{\mathrm{b}}( \pm 51.33)$ \\
\hline B114 & $16.2^{\mathrm{cd}}( \pm 0.75)$ & $92.4^{\mathrm{d}}( \pm 4.26)$ & $9.81^{\mathrm{fg}}( \pm 0.452)$ & $901.7^{\mathrm{e}}( \pm 41.56)$ \\
\hline B118 & $16.3^{\mathrm{c}}( \pm 0.76)$ & $89.0^{\mathrm{e}}( \pm 4.10)$ & $12.08^{\mathrm{c}}( \pm 0.557)$ & $1041.8^{\mathrm{c}}( \pm 48.02)$ \\
\hline P33 & $15.3^{\mathrm{e}-\mathrm{g}}( \pm 0.71)$ & $95.8^{\mathrm{c}}( \pm 4.42)$ & $12.08^{\mathrm{c}}( \pm 0.557)$ & $982.5^{\mathrm{d}}( \pm 45.28)$ \\
\hline P29 & $18.3^{\mathrm{b}}( \pm 0.84)$ & $84.7^{\mathrm{fg}}( \pm 3.90)$ & $12.96^{\mathrm{b}}( \pm 0.597)$ & $1147.5^{\mathrm{ab}}( \pm 58.02)$ \\
\hline P74 & $14.8^{\mathrm{g}}( \pm 0.68)$ & $75.5^{\mathrm{i}}( \pm 3.48)$ & $10.13^{\mathrm{f}}( \pm 0.467)$ & $851.7^{\mathrm{fg}}( \pm 39.25)$ \\
\hline P17 & $9.8^{\mathrm{j}}( \pm 0.45)$ & $73.5^{\mathrm{i}}( \pm 3.39)$ & $7.38^{\mathrm{i}}( \pm 0.340)$ & $611.8^{\mathrm{i}}( \pm 28.2)$ \\
\hline P21 & $19.8^{\mathrm{a}}( \pm 0.91)$ & $96.0^{c}( \pm 4.43)$ & $10.61^{\mathrm{e}}( \pm 0.489)$ & $790.7^{\mathrm{h}}( \pm 36.44)$ \\
\hline ZSB & $12.8^{\mathrm{i}}( \pm 0.59)$ & $86.3^{\mathrm{f}}( \pm 3.98)$ & $9.67^{\mathrm{g}}( \pm 0.446)$ & $859.7^{\mathrm{f}}( \pm 39.62)$ \\
\hline FYM & $15.5^{\mathrm{ef}}( \pm 0.71)$ & $83.5^{\mathrm{g}}( \pm 3.85)$ & $9.08^{\mathrm{h}}( \pm 0.418)$ & $819.3^{\text {gh }}( \pm 37.76)$ \\
\hline LSD & 0.57 & 2.0 & 0.42 & 35.5 \\
\hline
\end{tabular}

Values in the parentheses are standard errors and parameters were recorded at 60 DAS.

Values superscribed by the same alphabet are not significantly different according to Fisher's least significant difference test $(P<0.05)$.

RV: root volume; SL: shoot length; TDM: total dry mass; LA: leaf area.

TABLE 3: Macronutrients uptake pattern of maize, seed treated with ZSBs, and inorganic source of zinc.

\begin{tabular}{|c|c|c|c|c|c|c|}
\hline \multirow{2}{*}{ Treatment } & \multicolumn{6}{|c|}{ Macronutrients (\%) } \\
\hline & Total “P” & Total "N" & $\mathrm{K}$ & $\mathrm{Na}$ & $\mathrm{Ca}$ & $\mathrm{Na}: \mathrm{K}$ ratio \\
\hline Control & $0.18^{f}( \pm 0.160)$ & $1.428^{j}( \pm 0.160)$ & $1.6^{\mathrm{c}}( \pm 0.074)$ & $0.004^{\mathrm{d}}( \pm 0.00018)$ & $0.319^{\mathrm{d}}( \pm 0.015)$ & 0.0025 \\
\hline $\mathrm{ZnSO}_{4}$ & $0.15^{\mathrm{i}}( \pm 0.217)$ & $1.883^{\mathrm{bc}}( \pm 0.217)$ & $1.8^{\mathrm{b}}( \pm 0.083)$ & $0.005^{\mathrm{c}}( \pm 0.00023)$ & $0.434^{\mathrm{a}}( \pm 0.020)$ & 0.0028 \\
\hline Priming & $0.19^{\mathrm{e}}( \pm 0.150)$ & $1.568^{\mathrm{fg}}( \pm 0.150)$ & $1.5^{\mathrm{d}}( \pm 0.069)$ & $0.006^{\mathrm{b}}( \pm 0.00028)$ & $0.299^{\mathrm{g}}( \pm 0.014)$ & 0.004 \\
\hline B61 & $0.22^{\mathrm{b}}( \pm 0.170)$ & $1.848^{\mathrm{c}}( \pm 0.170)$ & $1.6^{\mathrm{c}}( \pm 0.074)$ & $0.004^{\mathrm{d}}( \pm 0.00018)$ & $0.339^{c}( \pm 0.016)$ & 0.0025 \\
\hline B40 & $0.28^{\mathrm{a}}( \pm 0.099)$ & $1.638^{\mathrm{de}}( \pm 0.099)$ & $1.8^{\mathrm{b}}( \pm 0.083)$ & $0.002^{\mathrm{f}}( \pm 0.00009)$ & $0.197^{\mathrm{k}}( \pm 0.009)$ & 0.0011 \\
\hline B116 & $0.11^{\mathrm{j}}( \pm 0.114)$ & $1.533^{\text {gh }}( \pm 0.114)$ & $1.4^{\mathrm{e}}( \pm 0.065)$ & $0.003^{\mathrm{e}}( \pm 0.00014)$ & $0.227^{\mathrm{j}}( \pm 0.010)$ & 0.0021 \\
\hline B114 & $0.16^{\mathrm{h}}( \pm 0.149)$ & $1.883^{\mathrm{bc}}( \pm 0.149)$ & $1.3^{\mathrm{f}}( \pm 0.060)$ & $0.001^{\mathrm{g}}( \pm 0.00005)$ & $0.298^{\mathrm{g}}( \pm 0.014)$ & 0.0008 \\
\hline B118 & $0.15^{\mathrm{i}}( \pm 0.156)$ & $1.673^{\mathrm{d}}( \pm 0.156)$ & $1.4^{\mathrm{e}}( \pm 0.065)$ & $0.004^{\mathrm{d}}( \pm 0.00018)$ & $0.311^{\mathrm{e}}( \pm 0.014)$ & 0.0029 \\
\hline P33 & $0.18^{\mathrm{f}}( \pm 0.171)$ & $1.603^{\mathrm{ef}}( \pm 0.171)$ & $1.5^{\mathrm{d}}( \pm 0.069)$ & $0.005^{\mathrm{c}}( \pm 0.00023)$ & $0.341^{c}( \pm 0.016)$ & 0.0033 \\
\hline P29 & $0.20^{\mathrm{d}}( \pm 0.052)$ & $2.268^{\mathrm{a}}( \pm 0.052)$ & $2.0^{\mathrm{a}}( \pm 0.092)$ & $0.005^{\mathrm{c}}( \pm 0.00023)$ & $0.104^{1}( \pm 0.005)$ & 0.0025 \\
\hline P74 & $0.17^{\mathrm{g}}( \pm 0.177)$ & $1.603^{\text {ef }}( \pm 0.177)$ & $1.5^{\mathrm{d}}( \pm 0.069)$ & $0.003^{\mathrm{e}}( \pm 0.00014)$ & $0.354^{\mathrm{b}}( \pm 0.016)$ & 0.002 \\
\hline P17 & $0.21^{c}( \pm 0.169)$ & $1.498^{\text {hi }}( \pm 0.169)$ & $1.3^{\mathrm{f}}( \pm 0.060)$ & $0.002^{\mathrm{f}}( \pm 0.00009)$ & $0.338^{\mathrm{c}}( \pm 0.016)$ & 0.0015 \\
\hline $\mathrm{P} 21$ & $0.17^{\mathrm{g}}( \pm 0.143)$ & $1.673^{\mathrm{d}}( \pm 0.143)$ & $1.4^{\mathrm{e}}( \pm 0.065)$ & $0.003^{\mathrm{e}}( \pm 0.00014)$ & $0.285^{\mathrm{h}}( \pm 0.013)$ & 0.0021 \\
\hline ZSB & $0.16^{\mathrm{h}}( \pm 0.152)$ & $1.463^{\mathrm{ij}}( \pm 0.152)$ & $1.5^{\mathrm{d}}( \pm 0.069)$ & $0.007^{\mathrm{a}}( \pm 0.00032)$ & $0.303^{\mathrm{f}}( \pm 0.014)$ & 0.0047 \\
\hline FYM & $0.18^{\mathrm{f}}( \pm 0.133)$ & $1.568^{\mathrm{fg}}( \pm 0.133)$ & $1.3^{\mathrm{f}}( \pm 0.060)$ & $0.002^{\mathrm{f}}( \pm 0.00009)$ & $0.266^{\mathrm{i}}( \pm 0.012)$ & 0.0015 \\
\hline LSD & 0.015 & 0.046 & 0.042 & 0.00012 & 0.002 & \\
\hline
\end{tabular}

Values in the brackets are standard errors and parameters were recorded at 60 DAS.

Values in the columns are means of two independent experiments with six replicates each time.

$\mathrm{ZnSO}_{4}$ alone was much similar to that of P29 treatment. P21 and P29 treated plants significantly enhanced the root volume and dry mass of plants, also supported by the studies carried out by Richardson [19], who showed that PGPR inoculation effectively increases surface area of roots and root weight [20]. The variation in enhancement of root volume by these strains may be due to the difference in the quantity of phytohormones produced by each strain. Auxin is a class of plant hormones of which indole-3-acetic acid is well studied, which has the capacity to enhance long term responses in plants [21]. Pseudomonas strains have increased root and shoot elongation in canola, lettuce, and tomato [22].

The plant growth promoting effects of bioinoculant PGPR strains were clearly demonstrated in many studies $[23,24]$. The positive effects of PGPRs on yield and growth of maize were explained by Egamberdiyeva [25], which may be due to $\mathrm{N}_{2}$ fixation ability, P-solubilizing capacity, and phytohormones production. 
TABLE 4: Micronutrients uptake pattern of maize, seed treated with ZSBs, and inorganic source of zinc.

\begin{tabular}{|c|c|c|c|c|c|}
\hline \multirow{2}{*}{ Treatment } & \multicolumn{5}{|c|}{ Micronutrients (ppm) } \\
\hline & $\mathrm{Zn}$ & $\mathrm{Mg}$ & $\mathrm{Fe}$ & $\mathrm{Cu}$ & $\mathrm{Mn}$ \\
\hline Control & $158.6^{\mathrm{i}}( \pm 7.3)$ & $0.16^{\text {cd }}( \pm 0.0074)$ & $481.4^{\mathrm{c}}( \pm 22)$ & $2.9^{\mathrm{c}}( \pm 0.13)$ & $34^{\mathrm{h}}( \pm 1.6)$ \\
\hline $\mathrm{ZnSO}_{4}$ & $188.6^{\mathrm{g}}( \pm 8.7)$ & $0.23^{\mathrm{a}}( \pm 0.0106)$ & $626.7^{\mathrm{b}}( \pm 29)$ & $4.8^{\mathrm{a}}( \pm 0.22)$ & $60^{\mathrm{a}}( \pm 2.8)$ \\
\hline Priming & $178.6^{\mathrm{h}}( \pm 8.2)$ & $0.15^{\mathrm{de}}( \pm 0.0069)$ & $488.4^{\mathrm{c}}( \pm 23)$ & $3.0^{c}( \pm 0.14)$ & $34^{\mathrm{h}}( \pm 1.6)$ \\
\hline B61 & $243.4^{\mathrm{c}}( \pm 11.2)$ & $0.17^{\mathrm{bc}}( \pm 0.0078)$ & $672.8^{\mathrm{a}}( \pm 31)$ & $2.9^{c}( \pm 0.13)$ & $51^{\mathrm{b}}( \pm 2.4)$ \\
\hline B40 & $192^{\mathrm{g}}( \pm 8.8)$ & $0.11^{\mathrm{h}}( \pm 0.0051)$ & $226.4^{\mathrm{f}}( \pm 10)$ & $3.7^{\mathrm{b}}( \pm 0.17)$ & $46^{\mathrm{c}}( \pm 2.1)$ \\
\hline B116 & $185.2^{\mathrm{gh}}( \pm 8.5)$ & $0.11^{\mathrm{h}}( \pm 0.0051)$ & $234.8^{\mathrm{f}}( \pm 11)$ & $1.5^{\mathrm{e}}( \pm 0.07)$ & $37^{\mathrm{fg}}( \pm 1.7)$ \\
\hline B114 & $235.2^{\mathrm{d}}( \pm 10.8)$ & $0.14^{\mathrm{ef}}( \pm 0.0065)$ & $367^{\mathrm{d}}( \pm 17)$ & $2.1^{\mathrm{e}}( \pm 0.10)$ & $40^{\mathrm{e}}( \pm 1.8)$ \\
\hline B118 & $231.8^{\text {de }}( \pm 10.7)$ & $0.15^{\mathrm{de}}( \pm 0.0069)$ & $282.7^{\mathrm{e}}( \pm 13)$ & $1.5^{\mathrm{e}}( \pm 0.07)$ & $24^{\mathrm{i}}( \pm 1.1)$ \\
\hline P33 & $225^{\mathrm{e}}( \pm 10.4)$ & $0.18^{\mathrm{b}}( \pm 0.0083)$ & $381^{\mathrm{d}}( \pm 18)$ & $0.9^{f}( \pm 0.04)$ & $38^{\mathrm{ef}}( \pm 1.8)$ \\
\hline P29 & $278.8^{\mathrm{a}}( \pm 12.8)$ & $0.04^{\mathrm{i}}( \pm 0.0018)$ & $155.2^{\mathrm{g}}( \pm 7)$ & $3.1^{\mathrm{c}}( \pm 0.14)$ & $60^{\mathrm{a}}( \pm 2.8)$ \\
\hline P74 & $230^{\text {de }}( \pm 10.6)$ & $0.16^{\mathrm{cd}}( \pm 0.0074)$ & $495^{\mathrm{c}}( \pm 23)$ & $1.9^{\mathrm{d}}( \pm 0.09)$ & $44^{\mathrm{cd}}( \pm 2.0)$ \\
\hline $\mathrm{P} 17$ & $259^{\mathrm{b}}( \pm 11.9)$ & $0.16^{\mathrm{cd}}( \pm 0.0074)$ & $381^{\mathrm{d}}( \pm 18)$ & $0.9^{f}( \pm 0.04)$ & $35^{\text {gh }}( \pm 1.6)$ \\
\hline $\mathrm{P} 21$ & $232^{\text {de }}( \pm 10.7)$ & $0.14^{\mathrm{ef}}( \pm 0.0065)$ & $707^{\mathrm{a}}( \pm 33)$ & $0.5^{\mathrm{g}}( \pm 0.02)$ & $25^{\mathrm{i}}( \pm 1.2)$ \\
\hline ZSB & $192^{\mathrm{g}}( \pm 8.8)$ & $0.13^{\mathrm{fg}}( \pm 0.0060)$ & $594^{\mathrm{b}}( \pm 27)$ & $0.7^{\mathrm{fg}}( \pm 0.03)$ & $43^{\mathrm{d}}( \pm 2.0)$ \\
\hline FYM & $212^{\mathrm{f}}( \pm 9.8)$ & $0.13^{\mathrm{fg}}( \pm 0.0060)$ & $359^{\mathrm{d}}( \pm 17)$ & $0.7^{\mathrm{fg}}( \pm 0.03)$ & $21^{\mathrm{j}}( \pm 1.0)$ \\
\hline LSD & 7 & 0.011 & 36.2 & 0.27 & 2.5 \\
\hline
\end{tabular}

Values in the brackets are standard errors and parameters were recorded at 60 DAS.

Values superscribed by the same alphabet are not significantly different according to Fisher's least significant difference test $(P<0.05)$.

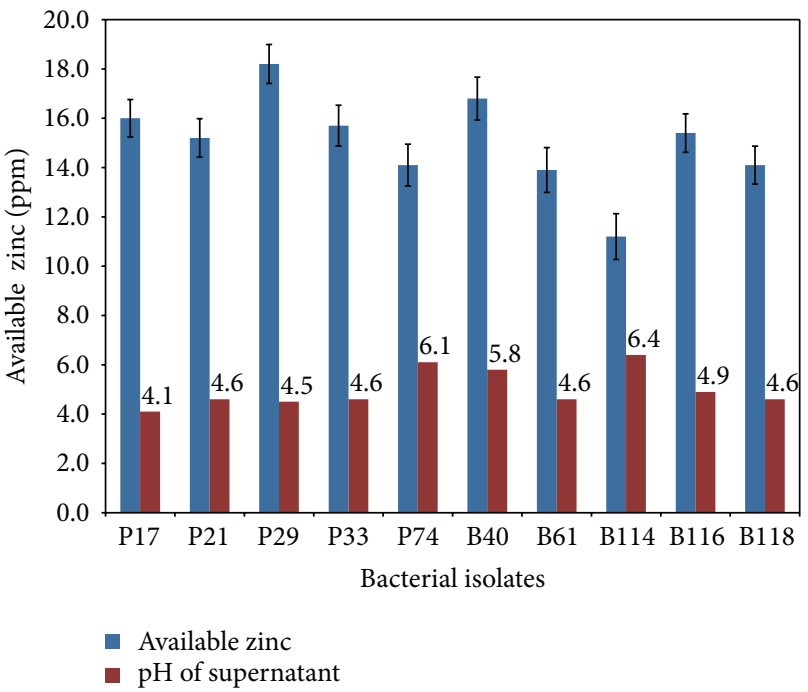

Figure 3: Available zinc $\left(\mathrm{mg} \cdot \mathrm{kg}^{-1}\right)$ released by bacteria in broth medium containing zinc oxide.

From the tabulated data in Tables $2-4$ it could be observed that no particular treatment with the bacterial strain or $\mathrm{ZnSO}_{4}$ or priming or FYM treatment could be able to enhance the growth of plants in all aspects. In case of dry mass and leaf area which were higher with the treatments where no bacteria were applied, much variation could not be seen on an overall comparison of treatments. This minor variation in between bacterial treatments could be due to difference in mechanisms of plant growth promotion exerted by different bacterial strains. Untreated plants showed poor growth.
In the current study, seed bacterization with zinc solubilizing plant growth promoting bacteria resulted in increased plant height (root volume and shoot height); leaf area; and dry mass. Similar increases in plant parameters were observed in different crops inoculated with Pseudomonas, Azospirillum, and Azotobacter strains [26, 27]. This improved growth by PGPR is due to making the increased availability of nutrients and decreasing metal toxicity [28].

The present study indicated that bacterial inoculation of maize with Pseudomonas and Bacillus significantly increased the nutrient content of " $\mathrm{N}$ " and " $\mathrm{P}$ " in leaves of maize (Table 3). This higher uptake of essential nutrients compared to uninoculated control plants could be justified from the fact that the unavailable forms of these nutrients were solubilized and made available in the root region by applying PGPR. Plants which are inoculated with plant growth promoting rhizobacteria usually have higher " $N$ " content than that of uninoculated plants [29]. This fact is further strengthened by studies conducted by Murty and Ladha [30] who demonstrated that Azospirillum inoculation increased phosphate and ammonium uptake in rice plants. Even though $\mathrm{K}^{+}$ concentration was higher in other treatments than control, similar trend was not seen in case of $\mathrm{Na}^{+}$levels (Table 3 ).

Results showed that all bacterial treated plants showed significant differences in $\mathrm{Fe}, \mathrm{Cu}, \mathrm{Mn}$, and $\mathrm{Zn}$ content in maize leaves (Table 4) although differences between various bacterial strains were insignificant. The enhancement of macro- and micronutrient uptake by plants by inoculation with PGPR may be due to their effect on initiation and development of lateral roots [31], increased root weight, and nutrient uptake [32]. Studies by Goldstein and Liu [33] showed that phosphate and potash solubilizing bacteria may enhance mineral uptake in plants. This evidence confirmed 
that the percentage of various nutrients estimated in maize plants was significantly and/or relatively increased in bacterial treated plants (Table 4). On observing the critical $\mathrm{Zn}$ levels of treatments it can be said that the $\mathrm{ZnSO}_{4}$ treatment recorded lower $\mathrm{Zn}$ levels compared to other treatments. This can be explained from the fact that the presence of readily available zinc source in soil itself is not sufficient for uptake, but also the mobility of the mineral element is required which can be clearly seen in bacterial treatments there by higher presence of zinc levels in maize plants treated with PGPR. A " $Z$ "-score statistical ranking method was followed to identify the promising bacterial isolate among all the strains and P29 strain was marked as the top strain compared to other bacteria for maize growth promotion.

\section{Conclusion}

Our study with PGPR and maize revealed that inoculation with beneficial rhizobacteria is an effective method for enhancing the growth of maize and maintaining the nutrient quality. Identified potential plant growth promoting rhizobacteria (P29) could be used as bioinput for improving the plant productivity as a substitute to chemical fertilizers and also to correct the nutrient deficiencies in maize for sustainable agriculture.

\section{Acknowledgment}

Financial support by Indian Council of Agricultural Research (ICAR), New Delhi, India, under a network project on Application of Microorganisms in Agriculture and Allied Sectors-Nutrient Management \& PGPR (AMAAS) is gratefully acknowledged.

\section{References}

[1] B. Singh, S. K. A. Natesan, B. K. Singh, and K. Usha, "Improving zinc efficiency of cereals under zinc deficiency," Current Science, vol. 88, no. 1, pp. 36-44, 2005.

[2] P. N. Sharma, C. Chatterjee, C. P. Sharma, and S. C. Agarwala, "Zinc deficiency and anther development in maize," Plant and Cell Physiology, vol. 28, no. 1, pp. 11-18, 1987.

[3] I. Cakmak, "Enrichment of cereal grains with zinc: agronomic or genetic biofortification?" Plant and Soil, vol. 302, no. 1-2, pp. $1-17,2008$.

[4] V. S. Saravanan, S. R. Subramoniam, and S. A. Raj, "Assessing in vitro solubilization potential of different zinc solubilizing bacterial (ZSB) isolates," Brazilian Journal of Microbiology, vol. 35, no. 1-2, pp. 121-125, 2004.

[5] F. L. Crane, I. L. Sun, and M. G. Clark, "Transplasma-membrane redox systems in growth and development," Biochimica et Biophysica Acta, vol. 811, no. 3, pp. 233-264, 1985.

[6] M. N. Hughes and R. K. Poole, "Metal speciation and microbial growth - the hard (and soft) facts," Journal of General Microbiology, vol. 137, no. 4, pp. 725-734, 1991.

[7] T. Wakatsuki, "Metal oxidoreduction by microbial cells," Journal of Industrial Microbiology, vol. 14, no. 2, pp. 169-177, 1995.

[8] H. Rodríguez and R. Fraga, "Phosphate solubilizing bacteria and their role in plant growth promotion," Biotechnology Advances, vol. 17, no. 4-5, pp. 319-339, 1999.
[9] V. S. Saravanan, P. Kalaiarasan, M. Madhaiyan, and M. Thangaraju, "Solubilization of insoluble zinc compounds by Gluconacetobacter diazotrophicus and the detrimental action of zinc ion $\left(\mathrm{Zn}^{2+}\right)$ and zinc chelates on root knot nematode Meloidogyne incognita," Letters in Applied Microbiology, vol. 44, no. 3, pp. 235-241, 2007.

[10] S. R. Olsen, C. V. Cole, F. S. Watanabe, and L. A. Dean, "Estimation of available phosphorus in soils by extraction with sodium bicarbonate," United States Department of Agriculture Circular, vol. 939, pp. 1-19, 1954.

[11] H. L. S. Tandon, Methods of Analysis of Soils, Plants, Water and Fertilisers, Fertiliser Develoment and Consultation Organisation, New Delhi, India, 2001.

[12] E. Nahas, "Factors determining rock phosphate solubilization by microorganisms isolated from soil," World Journal of Microbiology and Biotechnology, vol. 12, no. 6, pp. 567-572, 1996.

[13] J. A. Sayer and G. M. Gadd, "Solubilization and transformation of insoluble inorganic metal compounds to insoluble metal oxalates by Aspergillus niger," Mycological Research, vol. 101, no. 6, pp. 653-661, 1997.

[14] S. Seshadre, R. Muthukumarasamy, C. Lakshminarasimhan, and S. Ignaacimuthu, "Solubilization of inorganic phosphates by Azospirillum halopraeferans," Current Science, vol. 79, no. 5, pp. 565-567, 2002.

[15] F. Fasim, N. Ahmed, R. Parsons, and G. M. Gadd, "Solubilization of zinc salts by a bacterium isolated from the air environment of a tannery," FEMS Microbiology Letters, vol. 213, no. 1, pp. 1-6, 2002.

[16] C. Nguyen, W. Yan, F. Le Tacon, and F. Lapeyrie, "Genetic variability of phosphate solubilizing activity by monocaryotic and dicaryotic mycelia of the ectomycorrhizal fungus Laccaria bicolor (Maire) P.D. Orton," Plant and Soil, vol. 143, no. 2, pp. 193-199, 1992.

[17] C. D. Di Simine, J. A. Sayer, and G. M. Gadd, "Solubilization of zinc phosphate by a strain of Pseudomonas fluorescens isolated from a forest soil," Biology and Fertility of Soils, vol. 28, no. 1, pp. 87-94, 1998.

[18] S. Desai, G. Praveen Kumar, U. Sultana et al., "Potential microbial candidate strains for management of nutrient requirements of crops," African Journal of Microbiology Research, vol. 6, no. 17, pp. 3924-3931, 2012.

[19] A. E. Richardson, "Prospects for using soil microorganisms to improve the acquisition of phosphorus by plants," Australian Journal of Plant Physiology, vol. 28, no. 9, pp. 897-906, 2001.

[20] R. Çakmakçi, M. Erat, Ü. Erdoğan, and M. F. Dönmez, “The influence of plant growth-promoting rhizobacteria on growth and enzyme activities in wheat and spinach plants," Journal of Plant Nutrition and Soil Science, vol. 170, no. 2, pp. 288-295, 2007.

[21] R. Cleland, "Cell wall extension," Annual Review of Plant Physiology, vol. 22, pp. 197-222, 1971.

[22] B. R. Glick, C. Liu, S. Ghosh, and E. B. Dumbroff, "Early development of canola seedlings in the presence of the plant growth-promoting rhizobacterium Pseudomonas putida GR122," Soil Biology and Biochemistry, vol. 29, no. 8, pp. 1233-1239, 1997.

[23] M. I. El-Hawary, I. El-Hawary Fatma, A. M. El-Ghamry, and E. El-Naggar, "Effect of application of biofertilizer on the yield and NPK uptake of some wheat genotypes as affected by the biological properties of soil," Pakistan Journal of Biological Sciences, vol. 5, pp. 1181-1185, 2002. 
[24] S. C. Wu, Z. H. Cao, Z. G. Li, K. C. Cheung, and M. H. Wong, "Effects of biofertilizer containing $\mathrm{N}$-fixer, $\mathrm{P}$ and $\mathrm{K}$ solubilizers and AM fungi on maize growth: a greenhouse trial," Geoderma, vol. 125, no. 1-2, pp. 155-166, 2005.

[25] D. Egamberdiyeva, “The effect of plant growth promoting bacteria on growth and nutrient uptake of maize in two different soils," Applied Soil Ecology, vol. 36, no. 2-3, pp. 184-189, 2007.

[26] I. A. Siddiqui and S. S. Shaukat, "Zinc and glycerol enhance the production of nematicidal compounds in vitro and improve the biocontrol of Meloidogyne javanica in tomato by fluorescent pseudomonads," Letters in Applied Microbiology, vol. 35, no. 3, pp. 212-217, 2002.

[27] K. Shaukat, S. Affrasayab, and S. Hasnain, "Growth responses of Triticwn aestivum to plant growth promoting rhizobacteria used as a bio fertilizer," Research Journal of Microbiology, vol. 5, no. 10, pp. 1022-1030, 2010.

[28] G. I. Burd, D. G. Dixon, and B. R. Glick, "Plant growthpromoting bacteria that decrease heavy metal toxicity in plants," Canadian Journal of Microbiology, vol. 46, no. 3, pp. 237-245, 2000.

[29] M. E. Puente, C. Y. Li, and Y. Bashan, "Microbial populations and activities in the rhizoplane of rock-weathering desert plants. II. Growth promotion of cactus seedlings," Plant Biology, vol. 6, no. 5, pp. 643-650, 2004.

[30] M. G. Murty and J. K. Ladha, "Influence of Azospirillum inoculation on the mineral uptake and growth of rice under hydroponic conditions," Plant and Soil, vol. 108, no. 2, pp. 281285, 1988.

[31] B. G. Rolfe, M. A. Djordjevic, J. J. Weinman et al., "Root morphogenesis in legumes and cereals and the effect of bacterial inoculation on root development," Plant and Soil, vol. 194, no. 1-2, pp. 131-144, 1997.

[32] M. Y. Canbolat, S. Bilen, R. Çakmakçi, F. Şahin, and A. Aydin, "Effect of plant growth-promoting bacteria and soil compaction on barley seedling growth, nutrient uptake, soil properties and rhizosphere microflora," Biology and Fertility of Soils, vol. 42, no. 4, pp. 350-357, 2006.

[33] A. H. Goldstein and S. T. Liu, "Molecular cloning and regulation of a mineral phosphate solubilizing gene from Erwinia herbicola," Nature Biotechnology, vol. 5, no. 1, pp. 72-74, 1987. 

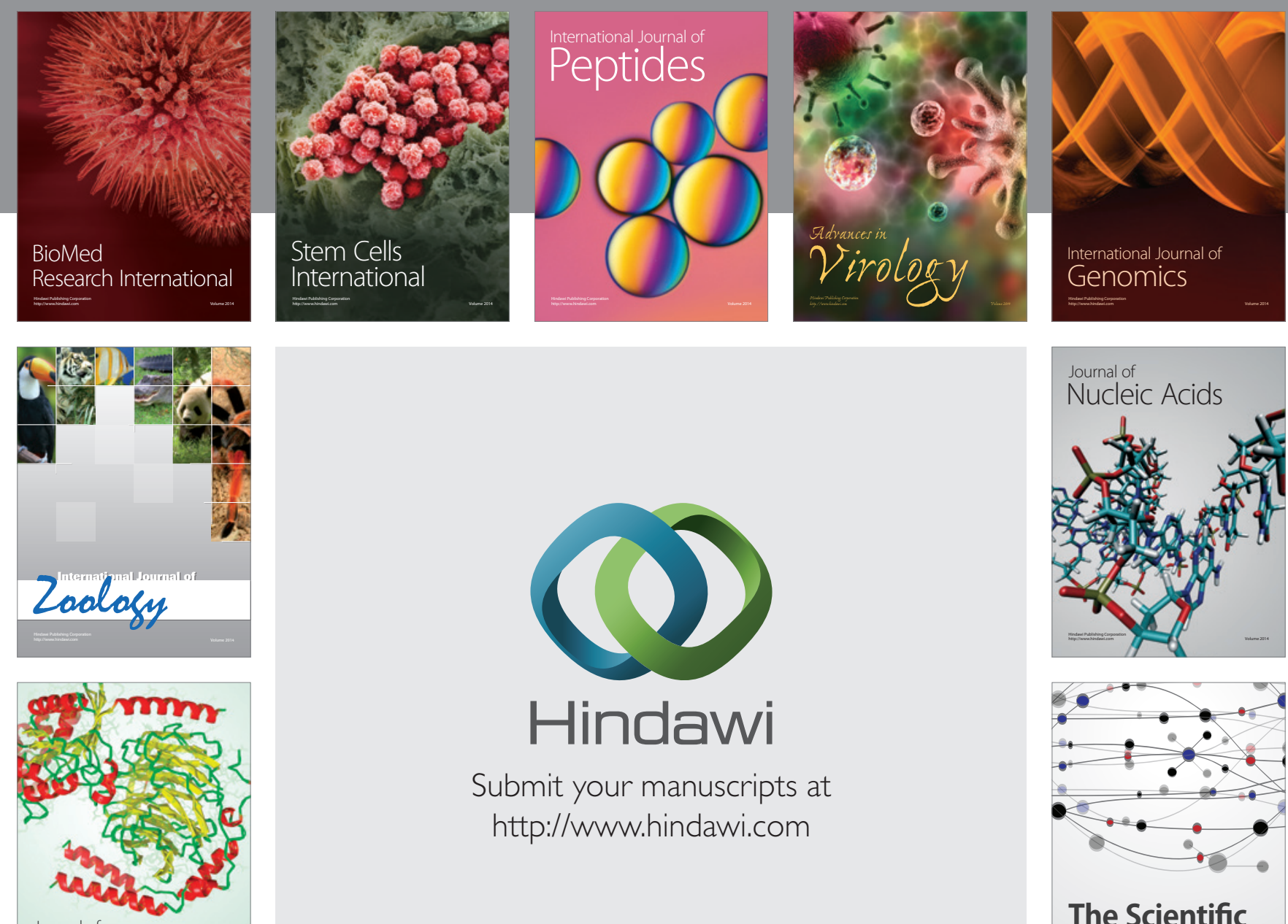

Submit your manuscripts at

http://www.hindawi.com

Journal of
Signal Transduction
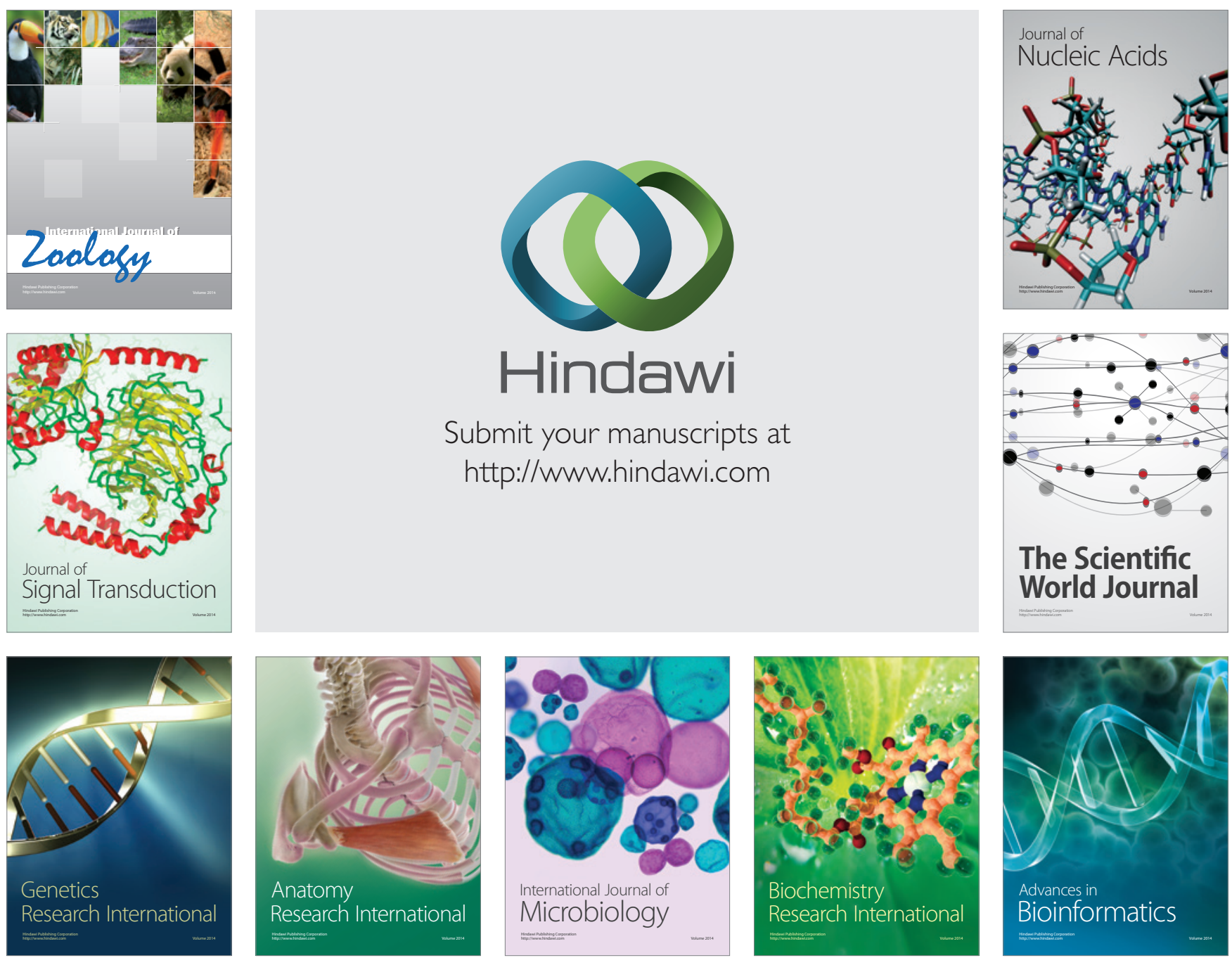

The Scientific World Journal
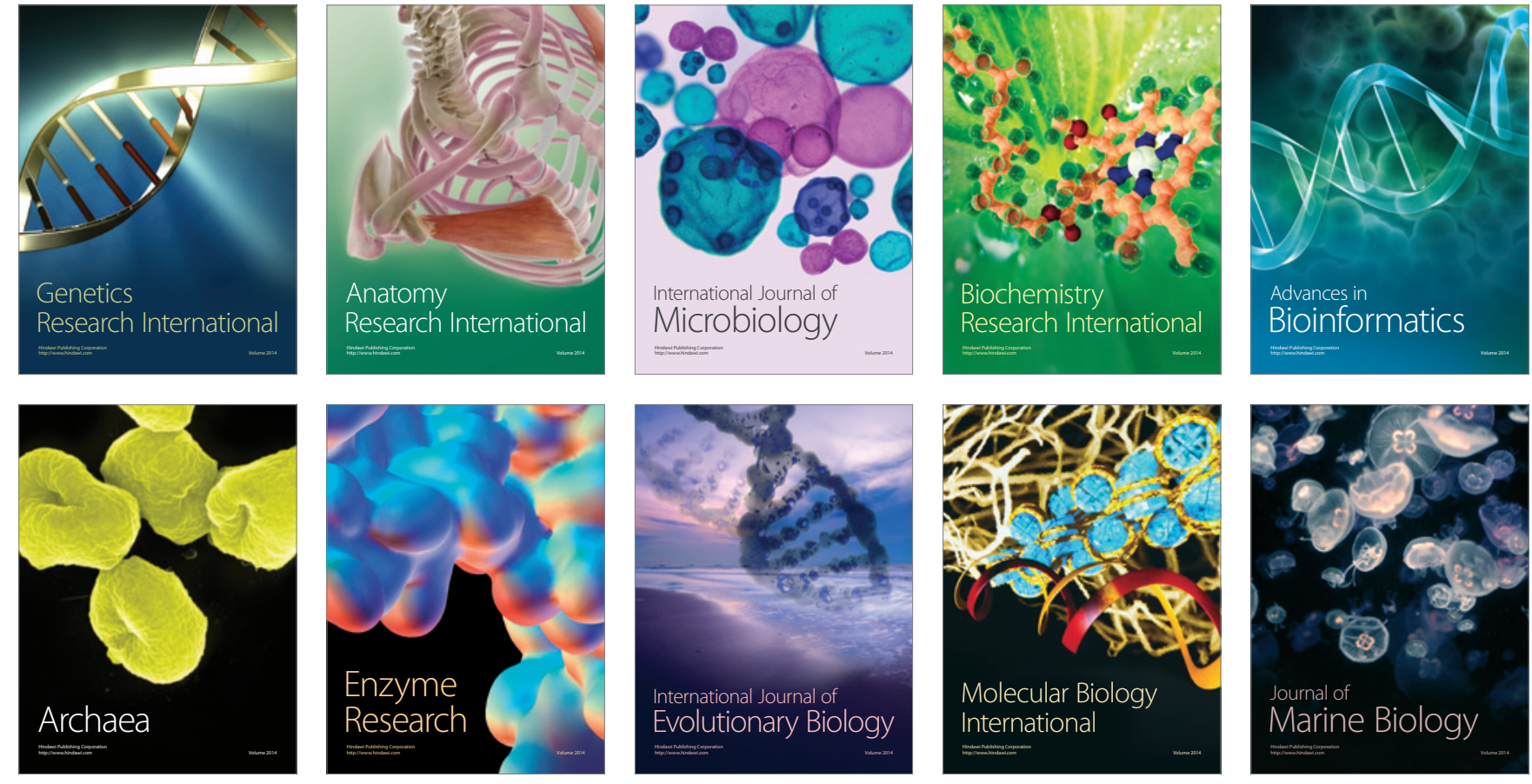